\title{
INVESTIGATION OF RESIDUAL STRESSES AND DISTORTION IN WELDED PIPE-FLANGE JOINT OF DIFFERENT CLASSES
}

\author{
MuHAMmad AbID AND SATTAR Ullah \\ GIK Institute of Engineering Sciences and Technology, Topi, Pakistan. \\ abid@giki.edu.pk
}

\begin{abstract}
Pipe and flange joints are commonly used in petrochemical, nuclear and process industries. Commonly, welding is used to make these joints which produce residual stresses and distortions. These stresses have detrimental effects on the structural integrity and service performance of the welded pipe joints. The objective of this study is to investigate the residual stresses and distortions during Gas Metal Arc Welding of pipe of schedule 40, nominal diameter $200 \mathrm{~mm}$ with different ANSI flanges of class numbers 150, 300, 600, 900, 1500, and 2500. Welding parameters including: voltage, current and heat as inputs were selected based on the literature available. The behaviour of the flanges of different classes is also discussed. In addition, the finite element methodology presented, in this paper, can be helpful for developing welding procedures for a range of pipe flange welded joint sizes in order to control the residual stresses and deformations. This will lead to optimised performance during bolt up and operating conditions.
\end{abstract}

ABSTRAK: Paip dan sambungan flan biasanya digunakan dalam industri petrokimia, nuklear dan proses. Kimpalan menghasilkan tegasan sisa dan herotan, yang memberikan kesan yang merbahaya ke atas integriti struktur dan prestasi servis sambungan kimpalan paip. Objektif kajian ini adalah untuk mengkaji tegasan sisa dan herotan ketika kimpalan arka logam gas paip berjadual 40, diameter nominal 200mm dengan flan ANSI yang berbeza kelas \# 150, 300, 600, 900, 1500, dan 2500. Parameter kimpalan termasuklah; voltan, arus dan haba input yang dipilih berdasarkan literatur sediada. Kelakuan flan yang berbeza kelas telah dibincangkan. Kaedah elemen finit yang dibentangkan adalah berguna dalam membangunkan prosedur kimpalan bagi julat saiz kimpalan flan paip unutk mengawal tegasan sisa dan canggaan i.e. bagi mengoptimakan prestasi ketika bolt up dan sedang beroperasi.

KEYWORDS: finite element; residual stresses; distortion; welding; pipe-flange joint; different classes

\section{INTRODUCTION}

The earliest welding technology can be traced to ancient time when forge welding was utilized in weapons. Electric fusion process is reported in 1782 in Germany by Lichtenberg [1], and electric arc welding process is reported in nineteenth century. The process of analytical determination of welding effect such as residual stresses and deformation started in mid 1940s and substantial work is observed in 1950s. This further led to the numerical modeling of heat flow and structural response during welding. Inherently, thermo-mechanical analysis of welding is non-linear due to non-linear thermal and structural material properties.

An analytical study by Vaidyanathan et al. [2] initially provided a method for the determination of residual stresses in thin walled cylindrical shells welded by single pass full penetration welds. Later work was extended [3] for a variety of the welding 
conditions, including multi-pass weld, partial penetration of weld and different materials for base and filler metals. Rybicki et al. [4-7] performed 2D FEA study for two pass weld for circumferential welding of stainless steel pipes. Jonsson and Josefson [8] performed experimental work in order to find transient strain and residual stresses in pipe. Josefson et al. [9] performed a comparative FEA study of 2D and 3D elements (solid and shell) to determine transient and residual stresses in a single-pass butt-welded pipe. Lindgren and Karlsson [10] developed a 3D model using shell elements to study deformation and stresses in welded thin walled pipes. For heat source distribution, analytical solution presented by Rosenthal [11] for moving line heat source in thin plates was used and temperature dependant material model was taken from Karlsson and Josefson $[12,13]$. Results were compared with [14] and were found in good agreement. It was concluded that 2D model may give reasonable results for residual stresses, but 3D model is necessary for transient and residual strains. Karlsson and Josefson [15] also analyzed a complete 3D FE model with solid elements for welding simulation of a pipe.

The effect of welding distortions and residual stresses on load carrying capacity of the pipe was studied by Troive et al. [16], using 3D FEA model for thin walled pipe with thermo-elasto-plastic shell elements with the same material model as used by Karlsson and Josefson in [15]. In order to find transient temperature history Rosenthal analytical solution [17] for a heat source with uniform strength along a line through the thickness of a plate was used. Troive et al. [18] extended their work for pipe-flange welding and concluded that the effect of geometrical size of pipe and flange is slightly greater than the one used in [16]. A new dental-foam method was developed for experimental measurement of axial distortions in flange. Teng and Chang [19] using axi-symmetric FE model for pipe-pipe joint, studied the effect of pipe diameter and wall thickness on residual stresses and results were found in agreement with the Rybicki et al. [20-21]. Abid and Siddique [22-35] has performed a detailed parametric welding simulation of pipeflange joints and have studied the effect of welding, geometric and other parameter on residual stresses and welding distortion. They concluded that the effect of decreasing current is almost similar to the increasing welding speed, at least for the range of parameters used in his study. They concluded that the main factor is the heat input per unit length of weldment, which has positive effect on the magnitude of the residual stresses and zone of influence. Pipe diameter has significant effect on the magnitude of residual stresses as well as on the zone of influence. Pipe wall thickness has negative effect on the magnitude of the residual stresses because pipe of smaller wall thickness has low stiffness and more prone to the radial shrinkage resulting bending stresses. They concluded that any change in tack weld location alters the axial displacement and tilt of the flange face. Regarding root gap opening it is found that root gap should be a minimum, just to meet the need of weld penetration. Large root gap increases lateral shrinkage and results in higher axial displacement and flange face tilt. Structural constraints were modeled representing welding fixture in girth welding of pipe-flange joints and to determine the effect of different constraints with the objective to minimized flange deformations. Abid and Jawad [36-39] have performed detailed three dimensional finite element analyses for multi pass welding. They have described the details of welding sequence; inter pass cooling and effect of different parameters on residual stresses and deformations.

\section{WELDING PARAMETERS}

Low carbon steel with chemical composition $0.18 \% \mathrm{C}, 1.3 \% \mathrm{Mn}, 0.3 \% \mathrm{Si}, 0.3 \% \mathrm{Cr}$, $0.4 \% \mathrm{Cu}$ is used in present work. Temperature dependant material properties are taken from Karlsson and Josefson [14]. As welding applies much localized heating on material, 
therefore they change the metallurgy, fluid flow, deformation and stresses of a material, however, in the present work, change in microstructure and fluid flow of a material is not taken in to account, and effect of welding on mechanical property is considered only. For conductivity, Goldak [40-41] assumed a value of $120 \mathrm{~W} / \mathrm{m}^{\circ} \mathrm{C}$ in the liquid range for low carbon steel. In order to model fluid flow (stirring) effect on the thermal field, thermal conductivity is given an artificial rise to $230 \mathrm{~kJ} / \mathrm{mK}$ at solidus temperature, as suggested by Anderson [42]. Temperature dependent specific heat value used in [42] is taken and latent heat of fusion of $260 \mathrm{~kJ} / \mathrm{kg}$ is specified for low carbon steel. Young's modulus of $12.4 \mathrm{GPa}$ is used, however even lower value of $1 \mathrm{GPa}$ is also reported in [43]. The values for both the bulk modulus and Poisson's ratio are taken constant after $1200{ }^{\circ} \mathrm{C}$.

\section{FINITE ELEMENT MODELING}

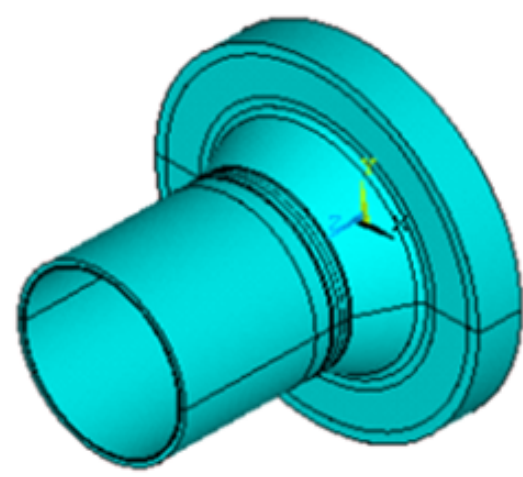

(a)

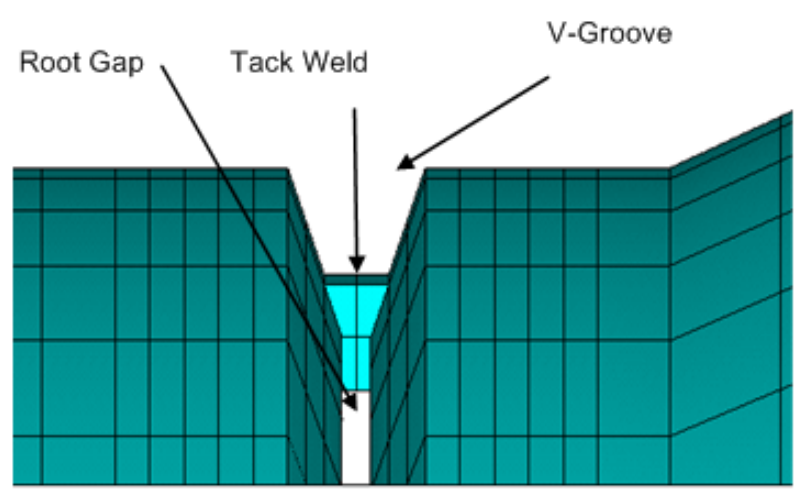

(b)

Fig. 1: (a) 3D solid model without bolt holes, (b) Tack weld geometry.

Weld neck flanges of ANSI Class \#150, 300, 600, 900, 1500, and 2500 [44] are analyzed during welding with pipe of length $200 \mathrm{~mm}$ of schedule 40 to observe residual stresses and displacement behavior during welding. Welding and geometrical parameters used are; Arc voltage 28 Volts; welding current 315 Amp; arc efficiency 85\%; surface area $90 \mathrm{~mm}^{2}$; welding speed $6.25 \mathrm{~mm} / \mathrm{sec}$; heat intensity $98 \mathrm{~W} / \mathrm{mm}^{2}$; nominal pipe diameter $200 \mathrm{~mm}$ and pipe thickness $8 \mathrm{~mm}$. Single pass GMAW welding using root gap of $1.2 \mathrm{~mm}$ is employed and bolt holes in the flange ring are neglected. Element length along radial direction and along circumferential direction is $2 \mathrm{~mm}$ and $9.44 \mathrm{~mm}$ respectively. Element length in the axial direction in melted and heat effected zone is $1.42 \mathrm{~mm}$.Weld tack location is 90 and 270 degree from weld start position as suggested by Abid and Siddique [23-25] and each tack length is $18.9 \mathrm{~mm}$ with thickness of $4 \mathrm{~mm}$. Tack welds also act as the boundary condition and restrain free body motion of the flange. Consequently, the stiffness of the tack welds (more precisely tack ring) is reduced to a very small value and permits unrestrained motion of the flange during the thermal cycle. For structural boundary condition all the node at the far end of the node is constrained to model pipe effect. 3D FEA takes about $113 \mathrm{sec}$ to complete circumferential weld with the welding sequence divided into 120 equally spaced solution steps of $0.941 \mathrm{sec}$ each. The stepped load option of ANSYS [45] is used for effective application of the thermal load during each load step. After extinguishing the arc, 48 load steps of different lengths are used for cooling of the weldment. It takes about 52 min to return to the ambient temperature of 27 ${ }^{\circ} \mathrm{C}$. Three dimensional pipe flange joint model and tack weld geometry is shown in Fig. 1. 


\section{HEAT SOURCE MODELING}

Goldak et al. [40-41] double ellipsoidal heat source model is used in the present work, as this has excellent characteristics of power density distribution control in the weld pool and HAZ. The heat source that was initially presented for plate welding is slightly modified in order to make it suitable for circumferential or hoop welding. For this purpose, the arbitrary candidate spatial location within the heat source is calculated by using cylindrical coordinate system. Geometry of the double ellipsoidal heat source is shown in Fig. 2a and dimension of double ellipsoidal heat source verified using MATLAB software shown in Fig. $2 b$.

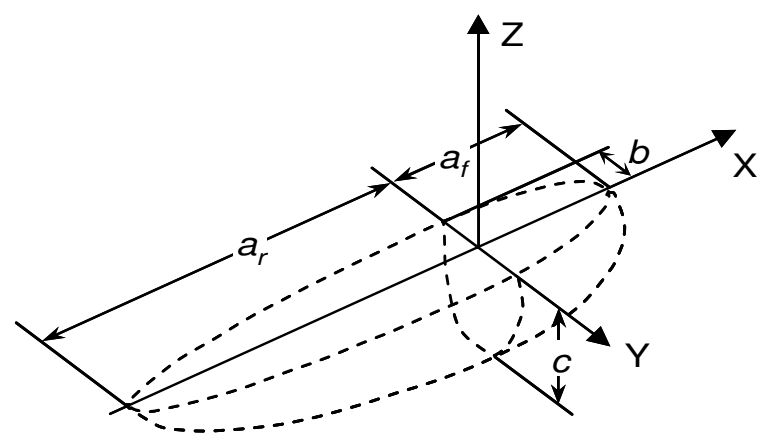

(a)

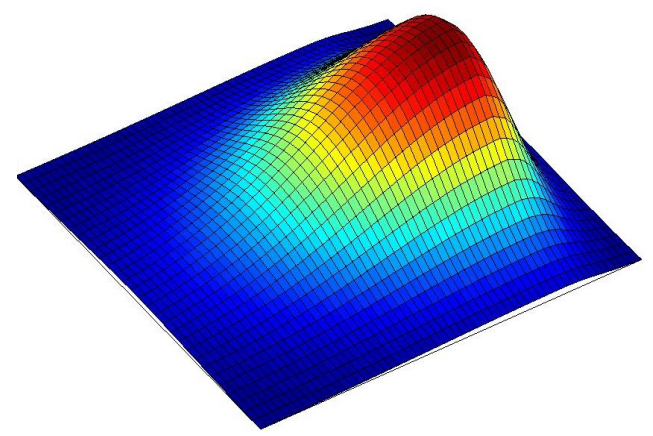

(b)

Fig. 2: (a) Geometry of double ellipsoidal heat source, (b) Power density distributions by using double ellipsoidal heat source model.

\section{ADDITION OF FILLER MATERIALS}

In the present work using finite element analysis software ANSYS, quiet element technique is used for its ease of implementation for analyses. In the quiet elements technique complete FE model, including all the elements and nodes of base metal and filler metal is developed at the start. The elements belonging to filler metal are deactivated by assigning them a very low thermal conductivity (in thermal analysis) and very low stiffness (in structural analysis). The value of thermal conductivity and stiffness should be as low as the deactivated elements may not have any contribution in the rest of the model but should not be as low which may produce an ill conditioned matrix. The elements belonging to a specific weld bead are reactivated by "element birth" option at the start of the respective weld bead or when they come under the influence of the welding torch. The material properties of reactivated elements are instated at the time of activation [46]. Temperature history at four different points $(3.5 \mathrm{~mm}, 5 \mathrm{~mm}, 10 \mathrm{~mm}$ and $20 \mathrm{~mm}$ distance of node from weld centerline) is shown in Fig. 3 and is observed in close agreement with the results in [23]. During fusion welding process, a very concentrated heat source is applied hence characteristics of heat source are determined by its intensity. Therefore, based on the data given in [47], heat intensity of $80 \mathrm{~W} / \mathrm{mm}^{2}$ and maximum torch speed of up to $7 \mathrm{~mm} / \mathrm{sec}$ is selected. 


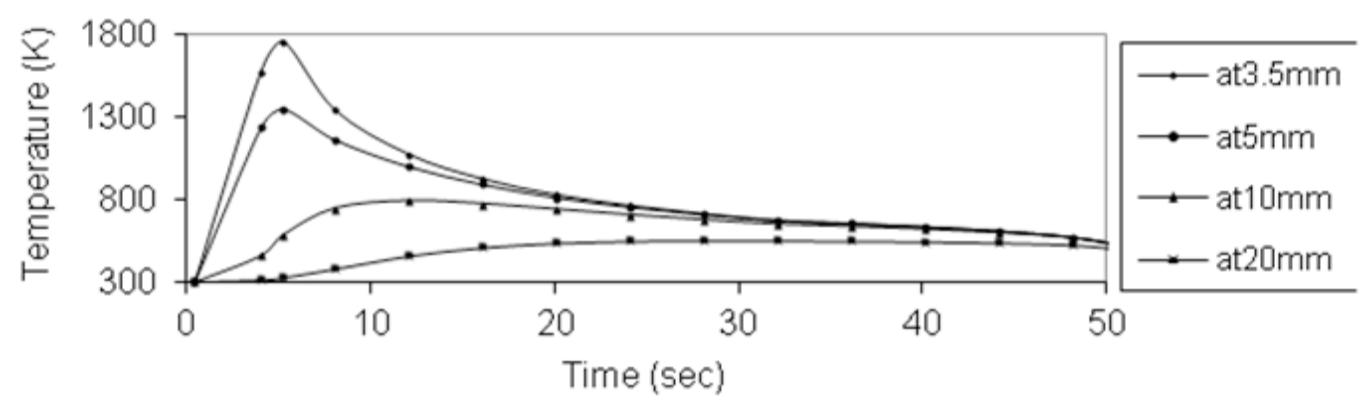

Fig. 3: Temperature histories.

\section{RESULTS AND DISCUSSION}

\subsection{Residual Stresses}

Results for axial and hoop residual stresses on pipe and flange at a section of 180 degree from weld start position at inner and outer diameters in the vicinity of weld center line are plotted in Fig. 4 and Fig. 5 respectively. It is observed that as flange class increases from 150 to 900 , residual stresses and their zone of influence increases and as flange classes increases from 1500 to 2500 , residual stresses and their zone of influence decreases at inner and outer diameter of pipe and flange. Classes 1500 ad 2500 are concluded to show less hoop stress variation compared to smaller, whereas axial stress observed is almost the same for all the sizes.

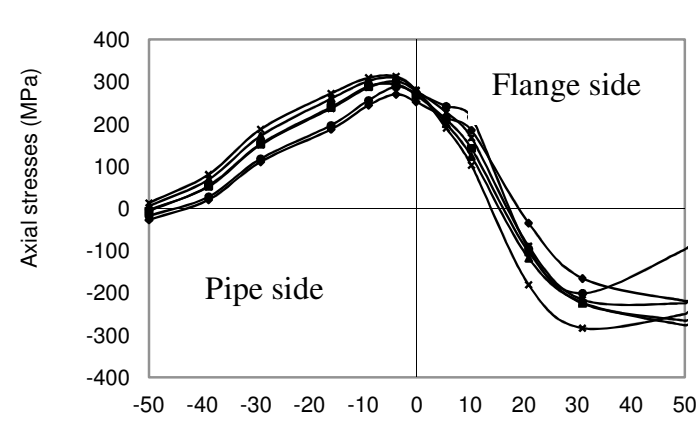

Distance from weld centre line $(\mathrm{mm})$

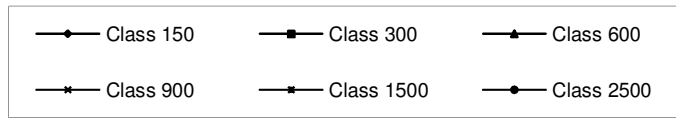

(a)

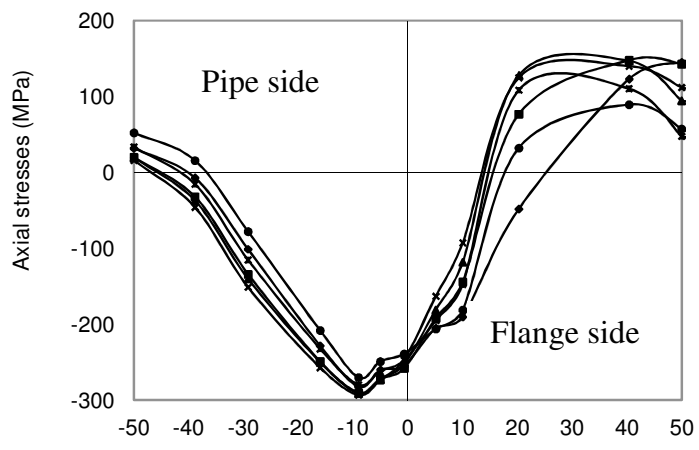

Distance from weld centre line $(\mathrm{mm})$

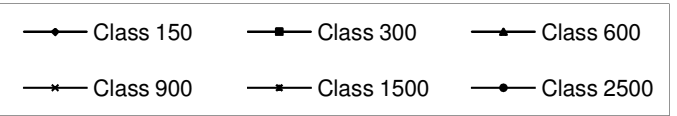

(b)

Fig. 4: Axial stresses; (a) inner and (b) outer diameter of pipe and flange. 


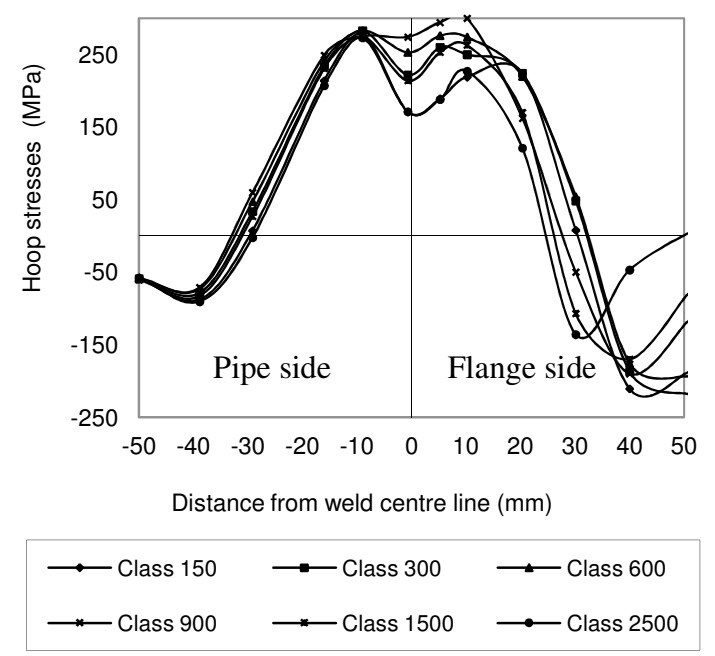

(a)

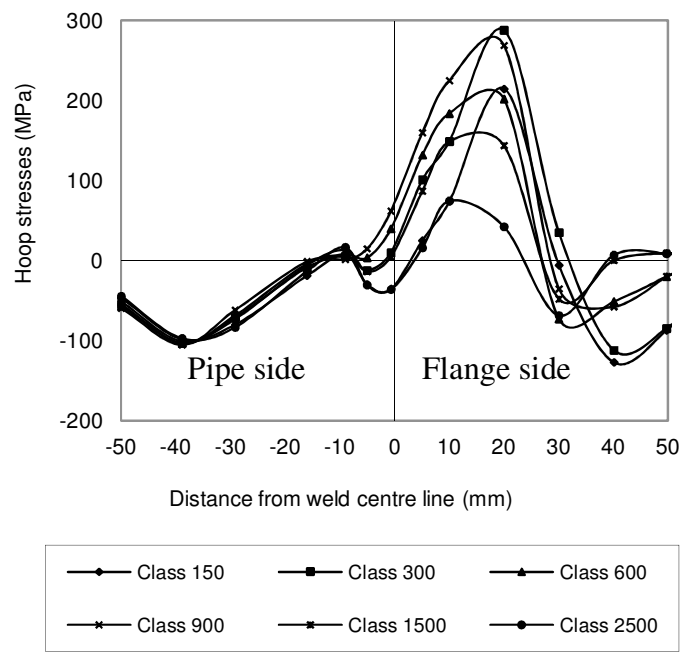

(b)

Fig. 5: Hoop stresses on (a) inner and (b) outer diameter of pipe and flange.

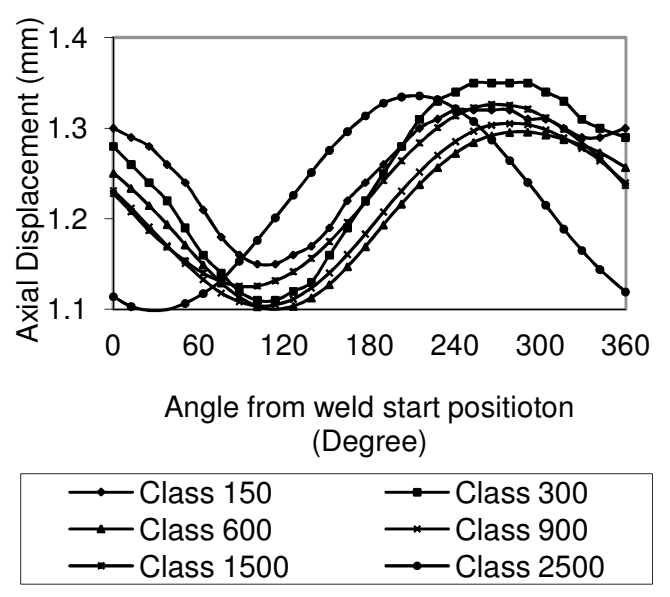

(a)

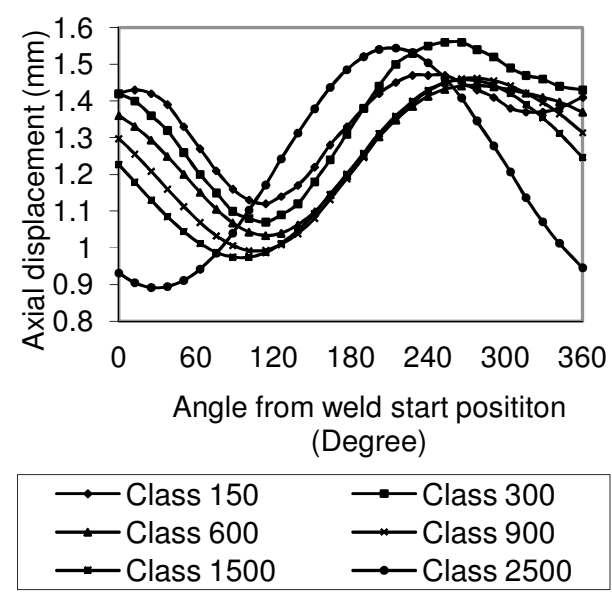

(b)

Fig. 6: Axial displacements on: (a) inner, (b) outer circumference at flange end.

\subsection{Axial Flange Displacement}

Axial flange displacement plots at inside and outside diameters of flange ring along 360degree location are plotted in Fig. 6. It is observed that as flange class increases from 150 to 1500 , axial displacement decreases from weld start position (zero degree) up to first tack (90 degree). Axial displacement increases from 90 degree i.e. first tack to 270 degree i.e. second tack. For flange class 2500, axial displacement slightly decreases up to 30 degree and then rapidly increases up-to 225 degree and then decreases almost to the same value at the start at 360degree location both at the inside and outside diameters of flange ring. 


\section{CONCLUSION}

Based on extensive parametric 3D finite element simulations for a range of flange classes, following conclusions are made;

- Stress variation on the flange side is more prominent due to its dimensional variation, whereas, on the pipe side a slight variation in all the classes is observed.

- Overall axial flange displacement along 360 degree is quite obvious and is the key finding to avoid gasket crushing, bolt scatter, bolt relaxation and hub flange yielding due to flange rotation. This ultimately affects sealing of the gasketed flanged pipe joints.

- Bolt holes in the flange ring are not modeled in this parametric study. However, with bolt holes in the flange, axial displacement may increases. Hence detailed analysis considering bolt holes in the flange will be performed in future work.

FE methodology presented can be helpful for developing welding procedures for a range of pipe flange welded joints for controlled residual stresses and deformations for optimized performance during bolt up and operating conditions.

\section{REFERENCES}

[1] "The Procedure Handbook of Arc Welding." $14^{\text {th }}$ Ed. The James F. Lincoln Arc Welding Foundation, Cleveland, USA, 2000.

[2] Vaidyanathan S., Todaro A.T., and Finnie, I. "Residual Stresses due to CircumferentialWelds." ASME J. Engineering Material and Technology 1973: 239-242.

[3] Rybicki, 8.F., Schmueser, D.W., Stonesifer, R.W., Groom, J.J., and Mishler, H.W., "A Finite

[4] Element Model for Residual Stresses and Deflections in Girth-Butt Welded Pipes."Journal of Pressure Vessel Technology 100(August, 1978): 256-262.

[5] Rybicki, E. F., and Stonesifer, R.8. "An Analysis of Weld Repair Residual Stresses for an

[6] Intermediate Test Vessel." Joumal of Pressure Vessel Technology 102(August 1980):32331.

[7] Rybicki, 8.F., and McGuire, P.A. "A Computational Model for Imp,roving Weld Residual

[8] Stresses in Small Diameter Pipes by Induction Heating." Journal of Pressure Vessel Technology 103(August, 1981): 294-9.

[9] Rybicki, E.F., and McGuire, P.A. "The Effects of Conduction Heating Conditions on Controlling Residual Stresses in Welded Pipes." Joumal of Engineering Materials and Technology 104 October, 1982: 267-273.

[10] Jonsson, M. and Josefson, B.L. "Experimentally Determined Transient and Residual Stresses in Butt-Welded Pipes." Journal of Strain Analysis 23.1(1988): 25-31.

[11] Josefson, L., Jonsson, M., Karlsson, L., Karlsson, R., Karlsson, T. and Lindgren L.E. "Transient and Residual Stresses in a Single-Pass Butt-Welded Pipe." ICRS-2, Nancy, France (1988): 23-25.

[12] Lindgren L.E. and Karlsson, L. "Deformations and Stresses in Welding of Shell Structures."International Journal Numerical methods in Engineering 25(1988): 635-55.

[13] Rosenthal, D. "The Theory of Moving Heat Source and its Application to Metal Treatment." Transaction ASME, 1946.

[14] Karlsson, R.I. and Josefson, B.L. "Three Dimensional Finite Element Analysis of Temperature and Stresses in a Single-Pass Butt-Welded Pipe." ASME Joumal of Pressure Vessel Technology 12(1990): 76-84.

[15] Karlsson, L., Jonsson, M., Lindgren, L.8., Nasstrom, M. and Troive, L., "Residual Stresses and Deformations in a Welded Thin-Walled Pipe." Proceedings of ASME Pressure Vessel 
and Piping Conference, Weld Residual Stresses and Plastic Deformation, Hawaii, 173(1989): 7-14.

[16] Jonsson, M. and Josefson, B.L. "Experimentally Determined Transient and Residual Stresses in the Butt-Welded Pipes." Journal of Strain Analysis 23.1(1988): 25-31.

[17] Karlsson, R.I. and Josefson, B.L. "Three Dimensional Finite Element Analysis of Temperature and Stresses in a Single-Pass Butt-Welded Pipe." ASME Joumal of Pressure Vessel Technology 12(1990): 76-8.

[18] Troive, L., Lindgren, L.E. and Jonsson, M. "Axial Collapse Load of Girth Butt-Welded Pipe."Proceedings of First International Symposium on Thermal Stresses and Related Topics, Japan: Shizuoka University, Hamamatsu 1995: 565-568.

[19] Rosenth I, D. "Theory of Moving Heat Source and its Application to Metal Treatment." Transaction ASME, 1946.

[20] Troive, L., Niisstrijm, M. and Jonsson, M. "Experimental and Numerical Study of MultiPass Welding Process of Pipe-Flange Joint." ASME Pressure Vessel Technology 120(1998):244-52.

[21] Troive, L. and Jonsson, M. "Numerical and Experimental Study of Residual Deformations Due to Double-J Multi-Pass Butt-Welding of a Pipe-Flange Joint." Proceedings of IEMS'94 (1994 Annual International Conference on Industry, Engineering and Management Systems), Florida USA: Cocoa Beach (1994): 107-1 14.

[22] Teng T.L. and Chang, P.H. "A Study of Residual Stresses in Multi-Pass Girth-Butt Welded Pipes." International Journal Pressure Vessels and Piping 74(1997): 59.

[23] Rybicki, E.F., McGuire, P.A., Merrick, 8., and Wert, E. "The Effect of Pipe Thickness on Residual Stresses due to Girth Welds." Journal of Pressure Vessel Technology 104(1982): 204-9.

[24] Rybicki, E.F., and Stonesifer, R.B. "Computation of Residual Stresses Due to Multipass Welds in PipingSystems.” Journal of PressureVesselTechnology 101(1979): 149-154.

[25] Muhammad Siddique. "Experimental and Finite Element Investigation of Residual Stresses and Distortion in Welded Pipe and Flange Joints." Ph.D Thesis, GIK Institute Topi, KPK, Pakistan. 2005.

[26] Muhammad Abid and Muhammad Siddique. "Welding Simulations for Pipe Flange Joints." VDM Verlag Dr.Muller, printed in the U.S.A. and in te U.K. (2009): 200.

[27] M. Abid, M.Siddique and R.A Mufti. "Prediction of Welding Distortion and Residual Stresses in a Pipe Flange Joint Using Finite Element Technique." Modelling and Simulation in Material Science and Engineering (2005): 454-70.

[28] Abid, M. and Siddique, M., Numerical Solution to Study the Effect of Tack Weld and Root Gap on Welding Deformation and Residual Stresses of Pipe Flange Joint. 82(2005): 860-71.

[29] M. Siddique, M. Abid, H. F. Junejo, R. A. Mufti. "3D finite element simulation of welding residual stresses in pipe-flange joints: effect of welding parameters." Journal of Material

[30] Science Forum 490-491 (2005): 79-85.

[31] M. Abid" M. Siddique, R.A. Mufti. "Prediction of welding distortions and residual stress in pipe, flange joint using finite element technique." Journal of Modelling and Simulation in Materials Science and Engineering 13 (2005): 455-70.

[32] M. Abid, M. Siddique. "Finite Element Simulation of Tack Welds in Girth Welding of Pipe Flauge Joint'nn.” Journal Acta Mechanica, 178. 1-2(2005): 5344.

[33] M. Abid, M. Siddique. "Numerical simulation to study the effect of tack welds and root gap on welding deformations and residual stresses of a pipe-flange joint." Intemational Journal of Pressure Vessels and Piping 82(2005): 860-71.

[34] Muhammad Abid, Muhammad Siddique. "Numerical Simulation of the effect of Constraints on Welding Deformations and Residual Stresses in a Pipe-Flange Joint." Journal of Modelling and Simulation in Materials Science and Engineering, Institute of Physics, 13 (2005): 919-33.

[35] M. Siddique, M. Abid. "Numerical Simulation of mechanical stress relieving in a multi-pass GTA girth welded pipe-flange joint to reduce fGSCC." Journal of Modelling and Simulation in Materials Science and Engineering, Institute of Physics 13 (2005): 13831402. 
[36] M. Siddique, M. Abid, H. F. Junejo. "3-D Finite Element Simulation of a single pass buttwelded pipe-flange joint." 2nd International Mechanical Engineering Congress (SIMEC 2003), Karachi, Pakistan, (Sep 26th - 28th 2003):1-12.

[37] M. Siddique, M. Abid, H. F. Junejo, R. A. Mufti. "Three dimensional finite element simulation of welding residual stresses in pipe-flange joints: effect of welding parameters." $7^{\text {th }}$ Inflation Conference on Residual Stresses in China llurlle 14-t7, 004: 1-8.

[38] M. Siddique, M. Abid and R. A. Mufti. "Simulation of welding distortions and Residual Stresses in pipe-flange joint using finite element Technique: Comparison of 2D and 3D models." International Mechanical Engineering Conference (IMEC2004), Kuwait (December 5-8, 2004): 614-91.

[39] Muhammad Abid, Muhammad Siddique. "A Study of Welding Deformations and Residual Stresses in a Pipe-Flange Joint: Effect of Constraints." Tehran International Congress on Manufacturing Engineering (TICME2005), Tehran, Iran (December 12-15, 2005): 1-8.

[40] M. Jawad Qami. "3D Thermo-Mechanical Finite Element Analysis of Residual Stresses and Distortions due to Multi-Pass Welding in Pipe Flange Joints.” MS Thesis. GIK Institute Topi, KPK, Pakistan. 2008.

[41] M. Abid and M. J. Qarni. "Numerical investigation of residual stresses and distortions due to multi-pass welding in a pipe flange joint." Process. Mech Part E: Journal Process Mechanical Engineering, 2241.4(2010): 253-67.

[42] M. Abid and M. J. Qarni. "3D thermal finite element analysis of single pass girth welded low carbon steel pipe-flange joints." Turkish Journal Engineering Environment Sciences 33(2009): 2841-293.

[43] Muhammad Abid, Muhammad Jawad Qarni. "3D Thermo-Mechanical Finite Element Analysis of Residual Stresses and Distortions due to Multi-pass Welding in Pipe Flange Joints." 3rd National Seminar on Welding Science and Technology, Islamabad Pakistan (July 2729, 2009): 1-9.

[44] Goldak, J., Bibby, M., Moore, J., House, R., Patel, B. "Computer Modeling of Heat Flow in Weld." Metallurgical Transactions B, 17(1986): 587-600.

[45] Goldak, J., Chakravarti, A. and Bibby, M. "A new Finite Element Model for Heat Sources" Metallurgical Transactions B, 15(1984): 299-305. vol. 15 B, pp. 299-305, 1984.

[46] Andersson, B.A.B. "Thermal Stresses in Submerged-Arc Welded Joint Considering Phase transformations." ASME Journal. Engineering Material and Technology 100(1978): 356

[47] 62. Lindgren, L.8. "Runnemalm, H. and Niisstrtim, M.O., Simulation of Multipass Welding of a Thick Plate." International Journal Numerical Methods Engineering 44(1999): 130116.

[48] British Standards Institution. "Circular Flanges for Pipes, Valves and Fittings." BS 1560: Section

[49] 3.1(1989). ANSYS Workbench Version 11. Engineering Data, Material Library, 2008.

[50] Lindgren, L.E. and Hedblom, R. "Modeling of Addition of Filler Material in Large Deformation

[51] Analysis of Multipass Welding." Communication in Numerical Methods in Engineering 17(2001): 647-51.

[52] Kelly Ferjutz, Joseph R. Davis, Nikki D. Wheaton. "ASM Handbook, Welding, Brazing and Soldering." 10th ed. Ohio: ASM International 6. 